\title{
Pemberdayaan Pelaku Ekonomi Sektor Melalui Peningkatan Pemahaman Konsep Wisata
} Syariah

\author{
Ansharullah $^{1,}$ Harum Natasha ${ }^{2,}$ Adam Malik Indra ${ }^{3}$ \\ ${ }^{1}$ UIN Sultan Syarif Kasim Riau \\ ${ }^{2}$ UIN Sultan Syarif Kasim Riau \\ ${ }^{3}$ UIN Sultan Syarif Kasim Riau
}

ARTICLE INFO ABSTRACT

Article history:

Received: 27 October 2018

Accepted: 20 November 2018

Published: 1 December 2018

Keywords:

Empowerment; Economic Actors;

Syaria Tourism.
The purpose of this dedication is to improve the understanding of the concept of sharia tourism for economic actors in the tourism sector, to improve services and to increase the income for economic actors in the tourism sector in Rokan Hulu regency, Riau province. The subject of this dedication is the economic actors in the tourism sector in the Great Islamic Center mosque in Rokan Hulu district. While the object is to increase the understanding of Islamic tourism. Empowerment methods are Participatory Learning and Action (PLA) Models, or Participatory Learning and Practical Processes by holding beginning and Final Competency Tests. Based on the results of dedication, it can be concluded that the knowledge and understanding of economic actors in the tourism sector at the Islamic Grand Mosque of Rokan Hulu district about the concept of sharia tourism is increased.

How to cite: Rullah, A. Pemberdayaan Pelaku Ekonomi Sektor Melalui Peningkatan Pemahaman Konsep Wisata Syariah. Jurnal Pemberdayaan Masyarakat Madani (JPMM), 2(2), 224-236. https://doi.org/https://doi.org/10.21009/JPMM.002.2.05

* Corresponding Author. 


\section{PENDAHULUAN}

\section{Analisis Situasi}

Pemberdayaan dapat diartikan sebagai suatu pelimpahan atau pemberian kekuatan (power) yang akan menghasilkan hierarki kekuatan dan ketiadaan kekuatan, seperti yang dikemukakan Simon (1993) bahwa pemberdayaan merupakan suatu aktvitas refleksi, suatu proses yang mampu diinisiasikan dan dipertahankan hanya oleh agen atau subyek yang mencari kekuatan atau penentuan diri sendiri (self-determination). Sulistiyani (2004) menjelaskan lebih rinci bahwa secara etimologis pemberdayaan berasal dari kata dasar "daya" yang berarti kekuatan atau kemampuan.

$$
\text { Pemberdayaan masyarakat atau }
$$
komunitas pramuwisata merupakan paradigma yang sangat penting dalam kerangka pengembangan kepariwisataan. Pentingnya pemberdayaan masyarakat dalam pengembangan tersebut oleh Murphy (1987) dikatakan bahwa pariwisata sebagai "community industry", sehingga keberlanjutan pembangunan pariwisata sangat tergantung dan ditentukan oleh dukungan, penerimaan, dan toleransi terutama dari masyarakat di sekitar kegiatan pariwisata (lokal). Memastikan bahwa pengembangan pariwisata di kabupaten Rokan Hulu dapat berkelanjutan, maka hal mendasar yang harus diwujudkan adalah memfasilitasi keterlibatan luas masyarakat lokal dalam proses pengembangan dan mengoptimalkan manfaat sosial budaya, lingkungan, dan ekonomi dari kegiatan wisata tersebut.

Fenomena di atas merupakan peluang yang menguntungkan bagi para pelaku industri pariwisata. Apalagi Kemenparekraf RI telah melakukan soft launching program pariwisata syariah pada bulan Desember 2012. Pengembangan dan mempromosikan usaha jasa bidang perhotelan, restoran, biro perjalanan wisata dan SPA di 12 destinasi wisata syariah termasuk provinsi Riau.

Selanjutnya, pada lingkup global pariwisata Indonesia berada pada peringkat 74 lebih tinggi dari Kamboja, Filipina, dan Vietnam yang merupakan negara tetangga dan tergabung dalam ASEAN. Peringkat pariwisata Indonesia di dunia dibandingkan dengan negara Asian Tenggara lainnya dapat dilihat pada tabel di bawah ini. Potensi Indonesia pada sektor pariwisata tentunya tidaklah kecil. Berdasarkan data UNESCO pada tahun 2018 ini, Indonesia memiliki 8 lokasi wisata yang menyandang gelar UNESCO Natural World Heritage Sites (2018). Kedelapan lokasi tersebut antara lain Taman Nasional Komodo, Taman Nasional Lorentz, Hutan Tropis Sumatera, Candi Borbudur, Candi Prambanan, Situs manusia purba Sangiran, Lanskap Budaya Provinsi Bali yaitu Sistem Subak dan hutan Ujung Kulon.

Dengan potensi yang ada tentunya target peningkatan jumlah wisatawan yang dinyatakan dalam RPJMN 2015-2019 tentunya dapat dimaksimalkan dengan berbagai program dan strategi pengembangan. Sektor pariwisata juga merupakan sektor potensial terkait dengan lapangan pekerjaan. Studi yang sama juga dilakukan oleh Master Card dan Crescent Rating dalam Global Muslim Travel Index (GMTI) 2015, bahwa pada tahun 2014 terdapat 108 juta wisatawan muslim yang merepresentasikan 10 persen dari keseluruhan industri wisata dan segmen ini mem- 
iliki nilai pengeluaran sebesar US\$145 miliar. Diperkirakan pada tahun 2020 angka wisatawan muslim akan meningkat menjadi 150 juta wisatawan dan mewakili 11 persen segmen industri yang diramalkan dengan pengeluaran menjadi sebesar US\$200 miliar.

Pentingnya wisatawan Muslim sekarang ini dapat dilihat dari tingkat belanja Muslim global pada pariwisata mencapai 137 miliar dollar pada tahun 2012 (tidak termasuk haji dan umrah), setara dengan $12,5 \%$ dari total pengeluaran global. Di masa yang akan datang, pengeluaran wisatawan Muslim diperkirakan akan tumbuh menjadi US\$ 181 miliar pada tahun 2018 (2013). Selain itu, berdasarkan data yang dilaporkan dalam Economic Creative Report 2013: Widening Local Development Pathway yang diterbitkan oleh UNESCO dan UNDP, pada saat ini pariwisata global sedang berlangsung trend dimana warisan budaya menjadi aset yang semakin berharga dan makin menyatu dengan pariwisata (2014). Data ini mengindikasikan bahwa unsur kebudayaan bisa menjadi daya tarik yang unik bagi wisatawan ketika berkunjung ke suatu daerah tujuan wisata termasuk di Indonesia.

Di beberapa negara di dunia, terminologi wisata syariah menggunakan beberapa nama yang cukup beragam diantaranya Islamic Tourism, Halal Friendly Tourism Destination, Halal Travel, Muslim-Friendly Travel Destinations, halal lifestyle, dan lain-lain. Pariwisata Syariah dipandang sebagai cara baru untuk mengembangkan pariwisata Indonesia yang menjunjung tinggi budaya dan nilai-nilai Islami. Selama ini wisata syariah dipersepsikan sebagai suatu wisata ke kuburan (ziarah) ataupun ke masjid. Padahal, wisata syariah tidak diartikan seperti itu, melainkan wisata yang di dalamnya berasal dari alam, budaya, ataupun buatan yang dibingkai dengan nilai-nilai Islam. Sedangkan, Kementerian Pariwisata dan Ekonomi Kreatif (Kemenparekraf) RI mendefinisikan Wisata Syariah sebagai kegiatan yang didukung oleh berbagai fasilitas serta layanan yang disediakan masyarakat, pengusaha, pemerintah dan pemerintah daerah yang memenuhi ketentuan syariah.

\section{Perumusan Masalah}

Permasalahan yang muncul di kabupaten Rokan Hulu provinsi Riau adalah masih kurangnya pemahaman pelaku ekonomi di sektor pariwisata tentang konsep wisata syariah itu sendiri. Kekurangan pemahaman konsep wisata syariah akan menimbulkan ketidakpuasan wisatawan terhadap kualitas pelayanan syariah yang disediakan. Pelayanan yang terbaik yaitu "melayani setiap saat, secara cepat dan memuaskan, berlaku sopan, ramah dan harus menolong serta professional dan mampu," sedangkan kualitas ialah "standar yang harus dicapai oleh seorang/kelompok/lembaga/ organisasi mengenai kualitas sumber daya manusia, kualitas cara kerja atau produk yang berupa barang dan jasa (2015).

Berdasarkan identifikasi masalah dimana ditemukan bahwa konsep wisata syariah masih baru, peluang wisata syariah sangat besar, belum maksimalnya pemahaman konsep wisata syariah, belum maksimalnya pelayanan di sektor pariwisata dan masih rendahnya pendapatan bagi para pelaku ekonomi di sektor pariwisata di kabupaten 
Rokan Hulu provinsi Riau, maka diperlukan kegiatan pendampingan kepada pelaku ekonomi di sektor pariwisata (Perhotelan, Restoran/ Penyedia makanan dan minuman, Biro perjalanan, Jasa SPA dan Pramuwisata) ditujukan untuk peningkatan sumber daya manusia yang menguasai beberapa pengetahuan dan keterampilan khusus (infoanekawisatarohul, 2017).

\section{Tujuan}

Adapun tujuan kegiatan pengabdian kepada masyarakat ini adalah memberikan pemahaman tentang konsep wisata Syariah pelaku ekonomi di sektor pariwisata di kabupaten Rokan Hulu provinsi Riau.

\section{Manfaat}

Kegiatan ini sangat memberikan manfaat khususnya bagi para pelaku ekonomi di sektor pariwisata di kabupaten Rokan Hulu provinsi Riau supaya mereka dapat memahami konsep wisata syariah. Lebih jauhnya, dengan pemahaman yang sudah diberikan dapat bermanfaat untuk meningkatkan potensi pariwisata Syariah di lingkungan tersebut.

\section{KAJIAN TEORITIK}

\section{Pariwisata Syariah dalam Al-Qur'an dan Hadits}

Surat Al-Ankabut [29] Ayat 20

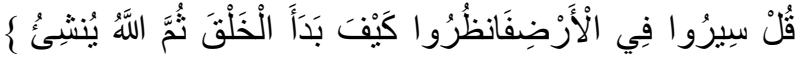

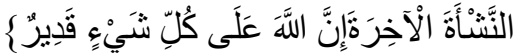

Artinya : "Katakanlah: Berjalanlah di bumi, maka perhatikanlah bagaimana Allah memulai penciptaan, kemudian Allah menjadikan ke- jadianyang lain. Sesungguhnya Allah Maha Kuasa atas segala sesuatu".

Surat Ar-Rum [30] Ayat 9

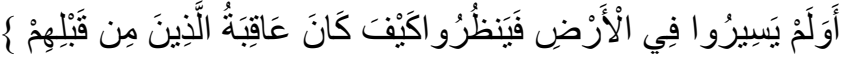

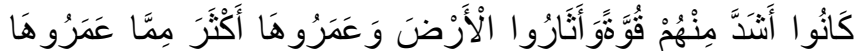

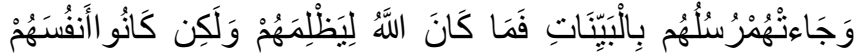
بَظْلْمِونَ

Artinya: "Apakah mereka tidak menjelajahi bumi, lalu melihat bagaimana kesudahan orang-orang sebelum mereka (yang mendustakan kebenaran yang dibawa rasul)? Orang-orang tersebut kuat dan telah mengelolah bumi serta memakmurkannya melebihi kemakmuran sebelumnya. Dan telah datang kepada mereka rasul-rasul mereka dengan membawa bukti-bukti yang jelas. Maka Allah sama sekali tidak mendzalimi mereka, tetapi merekalah yang berlaku dzalim kepada diri mereka sendiri”.

Surat Al-Hajj[22] Ayat 46

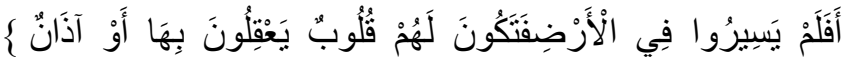

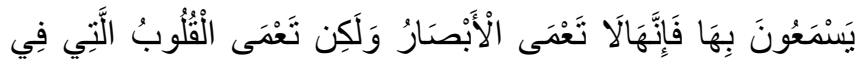
الصنُدُورِ

Artinya: "Tidak pernahkah mereka menjelajahi bumi, sehingga hati (akal) mereka dapat memahami,telinga mereka dapat mendengar?. Sebenarnya bukan mata itu yang buta, tetapi yang buta adalah hati yang di dalam dada”.

Hadits Tentang Memuliakan Tamu

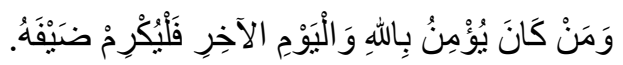

Artinya : "Barangsiapa beriman kepada Allah dan hari akhir, maka hendaklah ia memuliakan tamunya".

Namun, permasalahan yang muncul di kabupaten Rokan Hulu provinsi Riau adalah karena masih kurangnya pemahaman pelaku ekonomi di 
sektor pariwisata tentang konsep wisata syariah yang masih baru di samping peluang ekonominya yangn sangat besar. Kekurangan pemahaman konsep wisata syariah dapat menimbulkan ketidakpuasan wisatawan terhadap kualitas pelayanan syariah yang disediakan. Adapun tujuan pengabdian ini untuk dapat meningkatkan pemahaman sehingga bisa meningkatkan pelayanan dan meningkatkan pendapatan bagi para pelaku ekonomi di sektor pariwisata di kabupaten Rokan Hulu provinsi Riau.

Sementara itu, pelaku ekonomi di sektor pariwisata bedasarkan konsep wisata syariah adalah terdiri dari 5 komponen (2014) yaitu :

1. Perhotelan

2. Restoran/ Penyedia makanan dan minuman

3. Biro perjalanan

4. Jasa SPA

5. Pramuwisata

Pariwisata syariah memiliki karakteristik produk dan jasa yang universal, keberadaannya dapat dimanfaatkan oleh banyak orang. Produk dan jasa wisata, objek wisata, dan tujuan wisata dalam pariwisata syariah adalah sama dengan produk, jasa, objek dan tujuan pariwisata pada umumnya selama tidak bertentangan dengan nilai-nilai dan etika syariah dan berhubungan dengan konsep halal dan haram di dalam islam. Halal diartikan dibenarkan, sedangkan haram diartikan dilarang. Konsep halal dapat dipandang dari dua perspektif yaitu perspektif agama dan perspektif industri. Yang dimaksud dengan perspektif agama, yaitu sebagai hukum makanan apa saja yang boleh dikonsumsi oleh konsumen muslim sesuai keyakinannya. Ini membawa konsuekensi adanya perlindungan konsumen. Sedangkan dari perspektif industri. Bagi produsen pangan, konsep halal ini dapat diartikan sebagai suatu peluang bisnis. Bagi industri pangan yang target konsumennya sebagian besar muslim, diperlukan adanya jaminan kehalalan produk akan meningkatkan nilainya yang berupa intangible value. Contoh produk pangan yang kemasannya tercantum label halal lebih menarik bagi konsumen muslim (2015).

Menurut Chukaew (2015), terdapat delapan faktor standar pengukuran pariwisata syariah dari segi administrasi dan pengelolaannya untuk semua wisatawan yang hal tersebut dapat menjadi suatu karakteristik tersendiri, yaitu:

1. Pelayanan kepada wisatawan harus cocok dengan prinsip muslim secara keseluruhan;

2. Pemandu dan staf harus memiliki disiplin dan menghormati prinsipprinsip Islam;

3. Mengatur semua kegiatan agar tidak bertentangan dengan prinsip Islam;

4. Bangunan harus sesuai dengan prinsipprinsip Islam;

5. Restoran harus mengikuti standar internasional pelayanan halal;

6. Layanan transportasi harus memiliki keamanan sistem proteksi; 
7. Ada tempat-tempat yang disediakan untuk semua wisatawan muslim melakukan kegiatan keagamaan; dan

8. Bepergian ke tempat-tempat yang tidak bertentangan dengan prinsip Islam.

Dari karakteristik pariwisata syariah yang dijabarkan Chukaew (2015), terdapat empat aspek penting yang harus diperhatikan untuk menunjang suatu pariwisata syariah, yaitu:

1. Lokasi terkait penerapan sistem Islami di area pariwisata. Lokasi pariwisata yang dipilih merupakan yang diperbolehkan kaidah Islam dan dapat meningkatkan nilai-nilai spiritual wisatawan (2014).

2. Transportasi terkait penerapan sistem, seperti pemisahan tempat duduk antara laki-laki dan wanita yang bukan mahram.

3. Konsumsi terkait islam sangat memperhatikan segi kehalalan konsumsi, hal tersebut tertuang dalam Q.S Al-Maidah ayat 3. Segi kehalalan disini baik dari dari sifatnya, perolehannya maupun pengolahannya. Selain itu, suatu penelitian menunjukkan bahwa minat wisatawan dalam makanan memainkan peran sentral dalam memilih tujuan wisata (2012).

4. Hotel terkait seluruh proses kerja dan fasilitas yang disediakan berjalan sesuai dengan prinsip syariah. Menurut Rosenberg dalam Sahida (2012), pelayanan disini tidak sebatas dalam lingkup makanan maupun minuman, tetapi juga dalam fasilitas yang diberikan seperti spa, gym, kolam renang, ruang tamu dan fungsional untuk laki-laki dan perempuan sebaiknya terpisah.
Secara singkat, Riyanto (2012) melakukan komparasi pariwisata konvensional, pariwisata religi, dan pariwisata syariah sepertiyang tersaji dalam tabel 1.

Dalam aplikasinya, saat ini Kementerian Pariwisata dan BPH DSN-MUI telah merumuskan kriteria umum pariwisata syariah, yaitu berorientasi pada kemaslahatan umat; berorientasi pada pencerahan, penyegaran, dan ketenangan; menghindari kemusyrikan dan khurafat; menghindari maksiat seperti zina, pornografi, pornoaksi, minuman keras, narkoba dan judi; menjaga perilaku, etika, dan nilai luhur kemanusiaan seperti menghindari perilaku hedonis dan asusila; menjaga amanah, keamanan, dan kenyamanan; bersifat universal dan inklusif; menjaga kelestarian lingkungan; dan menghormati nilai-nilai sosial-budaya dan kearifan lokal (2014).

\section{MATERI DAN METODE}

\section{Kerangka Pemecahan Masalah}

Terkait dengan penjelasan metode pada gambar 1 sebagai metode belajar partisipatif, PLA memiliki beberapa prinsip sebagai berikut:

1. PLA merupakan proses belajar secara berkelompok yang dilakukan oleh semua stakeholders secara interaktif dalam suatu proses analisis bersama

2. Multi perspective, yang mencerminkan beragam interpretasi pemecahan masalah yang riil yang dilakukan oleh para pihak yang beragam dan berbeda cara pandangnya

3. Spesifik lokasi, sesuai dengan kondisi para pihak yang terlibat

4. Difasilitasi oleh ahli dan stakeholders (bukan 
anggota kelompok belajar) yang bertindak sebagai katalisator dan fasilitator dalam pengambil keputusan; dan (jika diperlukan) mereka akan meneruskannya kepada pengambil keputusan

5. Pemimpin perubahan, dalam arti bahwa keputusan yang diambil melalui PLA akan dijadikan acuan bagi perubahan-perubahan yang akan dilaksanakan oleh pelaku ekonomi sektor pariwisata di kabupaten Rokan Hulu provinsi Riau

Berkaitan dengan materi yang diberikan kepada kelompok sasaran, pengabdi memaparkan tentang karakteristik sebuah wisata syariah berdasarkan Fatwa Dewan Syariah Nasional MUI (2016). Bahwa penyelenggaraan wisata syariah wajib menghindari hal-hal yang tidak sesuai dengan syariat Islam seperti kemusyrikan, kemaksiatan dan kemungkaran. Disamping itu, hendaknya sebuah wisata Syariah mampu menciptakan kemaslahatan dan kemanfaatan baik secara material maupun spiritual. Demikian juga penjelasan tentang standar ukuran sebuah wisata syariah menurut Chukaew (2015), yaitu pelayanan yang sesuai dengan prinsip-prinsip seorang muslim. Selanjutnya, pemandu harus menghormati prinsip tersebut. Kegiatan yang dilakukan tidak bertentangan dengan prinsip Islam dan bangunan pun

\begin{tabular}{|c|c|c|c|c|}
\hline No & $\begin{array}{c}\text { Item } \\
\text { Perbandingan }\end{array}$ & Konvensional & Religi & Syari'ab \\
\hline 1 & Obyrel: & $\begin{array}{l}\text { Alam, budiayra, } \\
\text { heritage, kuliner }\end{array}$ & $\begin{array}{l}\text { Tempat ibadiah, } \\
\text { peninggalan } \\
\text { aejarah }\end{array}$ & Sermuanya \\
\hline 2 & Tujuan & MIenghibur & $\begin{array}{l}\text { Mreninglcatkam } \\
\text { apiritual }\end{array}$ & $\begin{array}{l}\text { MIeninglsarloan apirit } \\
\text { religivaitas dg } \\
\text { menghibur. }\end{array}$ \\
\hline 3 & Target & $\begin{array}{l}\text { MIenyentuh } \\
\text { kepruasan } \\
\text { dian lveaenangan } \\
\text { yang } \\
\text { bedimenai nafau, } \\
\text { untuk } \\
\text { menghibur } \\
\text { gemata. }\end{array}$ & $\begin{array}{l}\text { Aspel: apiritual } \\
\text { menenanglvan } \\
\text { jiwa, } \\
\text { mencari } \\
\text { lvetentraman } \\
\text { batin aemata. }\end{array}$ & $\begin{array}{l}\text { Mermenuhi keinginam } \\
\text { dam } \\
\text { kesenamgan serta } \\
\text { menumbuhlcan } \\
\text { kesadaram } \\
\text { beragama. }\end{array}$ \\
\hline 4 & Guide & $\begin{array}{l}\text { MIemahami dian } \\
\text { menguasai } \\
\text { informasi } \\
\text { sehingga bisa } \\
\text { menarik } \\
\text { wisatawan } \\
\text { terhadiap } \\
\text { obyrel: wisata. }\end{array}$ & $\begin{array}{l}\text { MIenguasai ajarah } \\
\text { tolroh dam lolkaai } \\
\text { yrang menjadi } \\
\text { obyrel; wiasta. }\end{array}$ & $\begin{array}{l}\text { MIembuat turia } \\
\text { tertarik pada } \\
\text { obyelk dan } \\
\text { mermbanglcitkan } \\
\text { spirit religiuaitas. } \\
\text { MIampu } \\
\text { menjelasan fungai } \\
\text { \& peran } \\
\text { ayrari'ah dlm } \\
\text { membentuk } \\
\text { kebahagiaan dan } \\
\text { kephasan } \\
\text { batin }\end{array}$ \\
\hline 5 & $\begin{array}{l}\text { Fasilitas } \\
\text { Tbadah }\end{array}$ & $\begin{array}{l}\text { selsediar } \\
\text { perlenglcapan }\end{array}$ & $\begin{array}{l}\text { Selsediar } \\
\text { perlenglcapan. }\end{array}$ & $\begin{array}{l}\text { MIenjadi bagiam yg } \\
\text { menyaru } \\
\text { dengam obryel: } \\
\text { pariwiaara, ritual } \\
\text { peribadatan menjadi } \\
\text { bagian } \\
\text { paket hiburam }\end{array}$ \\
\hline 6 & Kuliner & Unum & Umum & apeaifik yang halal \\
\hline 7 & $\begin{array}{l}\text { relasi dengam } \\
\text { maayaralcat di } \\
\text { lingluungan } \\
\text { obyrel: wiasta. }\end{array}$ & $\begin{array}{l}\text { lsomplementer } \\
\text { dam } \\
\text { sermata-mata } \\
\text { mengejar } \\
\text { keumtumgan }\end{array}$ & $\begin{array}{l}\text { komplementer dian } \\
\text { mengejar } \\
\text { keuntumgan } \\
\text { gemata. }\end{array}$ & $\begin{array}{l}\text { terintegrasi, interalsai } \\
\text { berdasar prinsip- } \\
\text { prinsip } \\
\text { syari'ah. }\end{array}$ \\
\hline 8 & $\begin{array}{l}\text { Agendia } \\
\text { Perjalanan }\end{array}$ & $\begin{array}{l}\text { MIengabaiksan } \\
\text { wraktun }\end{array}$ & $\begin{array}{l}\text { Pediuli walktu } \\
\text { perjalanam }\end{array}$ & $\begin{array}{l}\text { MIemperhatikan } \\
\text { walutu. }\end{array}$ \\
\hline
\end{tabular}

Tabel 1

Perbandingan pariwisata syariah dengan lainnya 
harus sesuai dengan prinsip Islam. Yang tak kalah penting juga pemaparan tentang restauran atau tempat bersantap yang sesuai standar internasional pelayanan yg halal.

\section{Realisasi Pemecahan Masalah}

Pengabdi memberikan materi tentang karakteristik sebuah wisata syariah berdasarkan Fatwa Dewan Syariah Nasional MUI (2016). Menjelaskan kewajiban penyelenggaraan wisata syariah dalam menghindari segala hal yang tidak sesuai dengan syariat Islam. Tambahan materi tentang wisata Syariah yang mampu memberikan maslahat yang baik secara material dan spiritual. Standar ukuran sebuah wisata syariah menurut Chukaew (2015): pelayanan yang sesuai dengan prinsip-prinsip seorang muslim, kegiatan tidak bertentangan dengan prinsip Islam dan bangunan yang sesuai dengan prinsip Islam. Serta pemaparan tentang restauran dengan pelayanan yg halal.

\section{Khalayak Sasaran}

Adapun kelompok sasaran yang strategis diarahkan pada:

1. Penguatan kapasitas dan pemahaman tentang konsep wisata syariah pelaku ekonomi sektor pariwisata untuk turut serta aktif dalam kegiatan dan proses pembangunan kepariwisataan di kabupaten Rokan Hulu provinsi Riau, diantaranya:

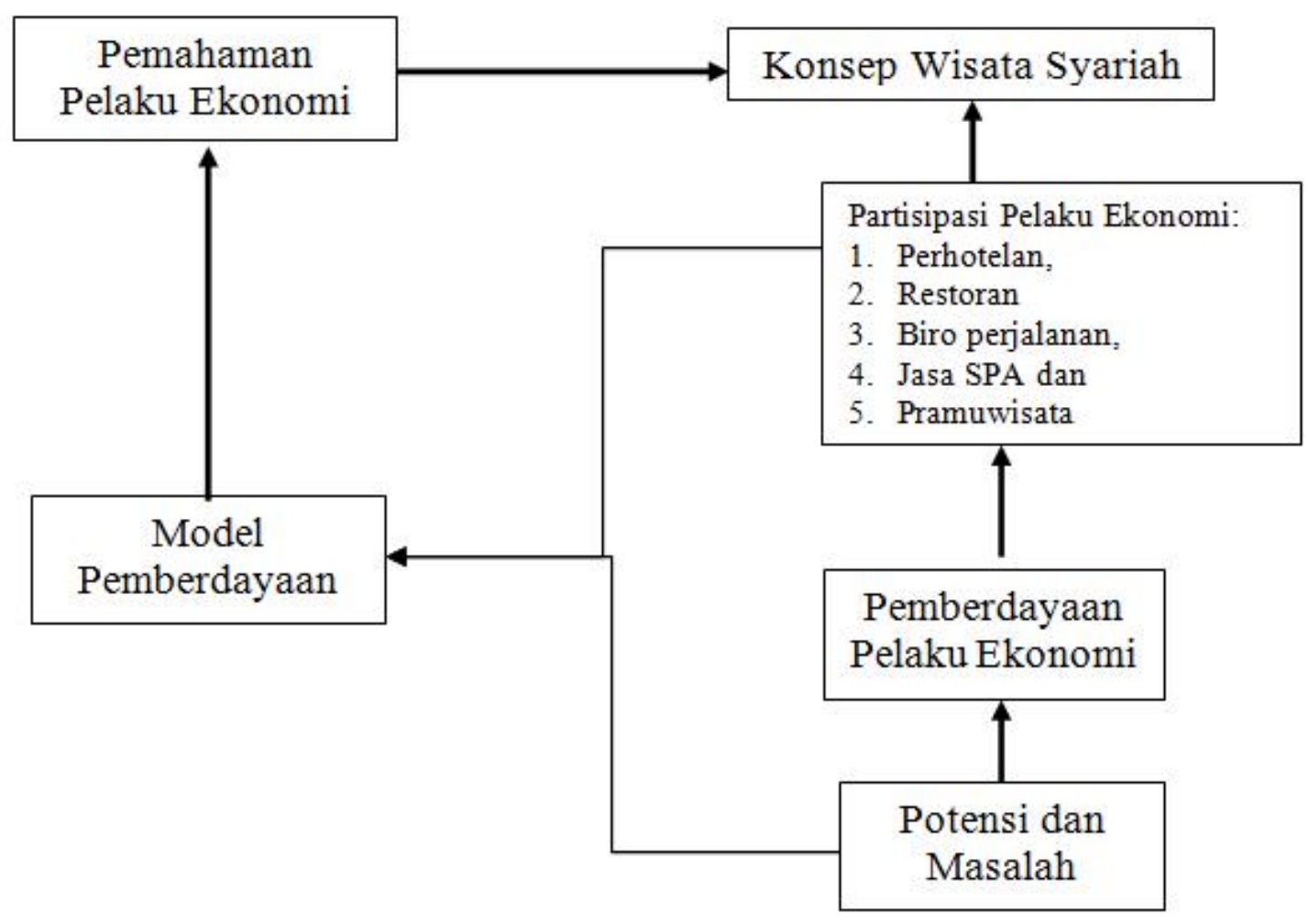

Gambar 1

Alur fikir pemberdayaan pelaku ekonomi sektor pariwisata 
a. Kapasitas institusi yaitu pemerintah, perguruan tinggi, dan organisasi non pemerintah.

b. Pelibatan dalam proses pengembangan (perencanaan, implementasi, dan monitoring/evaluasi)

2. Penguatan akses dan kesempatan berusaha bagi pelaku ekonomi sektor pariwisata di kabupaten Rokan Hulu provinsi Riau untuk meningkatkan manfaat ekonomi kawasan wisata syariah, diantaranya:

a. Meningkatnya suplai terhadap fasilitas penunjang pariwisata yaitu akomodasi, makanan dan minuman, serta cindramata.

b. Menyediakan pemasukan tambahan bagi penyedia barang dan jasa layanan pelaku ekonomi sektor pariwisata

c. Meningkatkan permintaan pasar terhadap produk lokal, sehingga akan mendorong keberlanjutan adat tradisi masyarakat local

d. Menggunakan tenaga kerja dan tenaga ahli lokal untuk menjadi pelaku ekonomi sektor pariwisata

e. Membuka sumber dana bagi usaha perlindungan atau konservasi sumberdaya alam dan sumberdaya budaya

\section{Metode}

Metode yang digunakan dalam kegiatan adalah pmberdayaan PLA (Participatory Learning and Action), atau Proses Belajar dan Praktek Secara Partisipatif. PLA merupakan bentuk baru dari metode pemberdayaan masyarakat yang dahulu dikenal sebagai "learning by doing" atau belajar sambil beker- ja. Secara singkat, PLA merupakan metoda pemberdayaan masyarakat yang terdiri dari proses belajar tentang suatu konsep pariwisata syariah yang segera setelah itu diikuti aksi atau kegiatan riil yang relevan dengan materi pemberdayaan pelaku ekonomi di sektor pariwisata kabupaten Rokan Hulu provinsi Riau. Melalui kegiatan PLA, akan diperoleh beragam manfaat, berupa:

1. Segala sesuatu yang tidak mungkin dapat dijawab oleh "orang luar"

2. Pelaku ekonomi sektor pariwisata akan memperoleh banyak pengetahuan yang berbasis pada pengalaman yang dibentuk dari lingkungan kehidupan mereka yang sangat komplek

3. Pelaku ekonomi sektor pariwisata di kabupaten Rokan Hulu provinsi Riau akan melihat bahwa mereka lebih mampu untuk mengemukakan masalah dan solusi yang tepat dibanding orang luar

4. Melalui PLA, pengabdi dapat memainkan peran penghubung antara masyarakat setempat dengan lembaga lain yang diperlukan. Disamping itu, pengbadi dapat menawarkan keahlian tanpa harus memaksakan kehendaknya.

\section{HASIL DAN PEMBAHASAN}

\section{Hasil Kegiatan}

Berdasarkan wawancara, tanya jawab dan pengamatan langsung selama kegiatan berlangsung, kegiatan pengabdian pada masyarakat ini memberikan hasil yang sangat memuaskan. Ini dapat dilihat pada hasil pretest dan post test peserta dibawah ini.

Dari tabel 2 dapat dijelaskan bahwa nilai 
dari uji kompentensi awal dari peserta no 4 (empat) dan 6 (enam) sebesar 40 poin dan 30 poin telah mengalami peningkatan nilai yang sangat signifikan pada nilai uji kompetensi akhir sebesar 100 poin dan 90 poin. Sedangkan peningkatan nilai yang paling rendah adalah peserta no 5 (lima) yang hanya mengalami peningkatan nilai dari 70 poin pada uji kompetensi awal menjadi 80 poin pada hasil ujian kompetensi akhir. Ini lebih disebabkan karena kurang serius dalam mendengarkan penjelasan dari narasumber.

Dari uji kompetensi ini diharapkan pihak terkait mampu membangun sebuah konsep wisata syariah yang tidak keluar dari jalur Syariat Islam. Pemahaman akan konsep tersebut bisa meningkatkan issue syariah dalam im- plementasinya pada objek wisata. Sehingga, setiap element di dalam sebuah pariwisata dapat berjalan dengan baik sesuai kaidah syariah.

Ketika seluruh lini tidak memahami konsep syariah ini, maka akan terjadi ketidaksiapan pihak terkait. Fenomena tersebut dibuktikan oleh Andriani (2015) dalam penelitiannya tentang pihak penyelenggara wisata Syariah. Pertama, bahwa responden terkait wisata syariah di Manado yang berkaitan dengan pengembangan wisata syariah, travel syariah, promosi dan publikasi, sertifikasi halal, amenitas, aksesibilitas, pramuwisata, SPA, sanitasi (kebersihan), dan harga. Yang paling disoroti adalah ketersediaan toilet dan tempat berwudhu yang terpisah antara laki-laki dan perempuan terutama di lokasi daya tarik wisata. Diperlukan pula sertifikasi halal dari MUI untuk

\begin{tabular}{|c|c|c|}
\hline Peserta & Nilai Uji Kompetensi Awal & Nilai Uji Kompetensi Awal \\
\hline 1 & 50 & 80 \\
\hline 2 & 70 & 100 \\
\hline 3 & 50 & 90 \\
\hline 4 & 40 & 100 \\
\hline 5 & 70 & 80 \\
\hline 6 & 30 & 90 \\
\hline 7 & 60 & 100 \\
\hline 8 & 50 & 80 \\
\hline 9 & 40 & 90 \\
\hline 10 & 50 & 80 \\
\hline
\end{tabular}

Sumber: Data Olahan

Tabel 2

Hasil uji kompetensi awal dan akhir peserta dalam upaya peningkatan pemahaman pelaku ekonomi sektor pariwisata di Mesjid Agung islamic centre kabupaten Rokan Hulu tentang konsep wisata syariah 
restoran dan penyedia jasa makanan dan minuman lainnya karena sertifikasi halal memberikan rasa nyaman bagi wisatawan muslim. Berkaitan dengan praktik SPA yang harus sesuai syariah. Masalah promosi dan publikasi wisata syariah juga banyak disoroti responden. Kurangnya informasi mengenai wisata syariah membuat sebagian responden tidak memahami implementasi teknis dari prinsip-prinsi syariah dalam berwisata. Contoh mudah ketika ditanyakan mengenai travel syariah $44 \%$ responden menyatakan tidak tahu. Masalah kebersihan di lokasi daya tarik wisata dan biaya transportasi yang sesuai dengan standar juga menjadi permasalahan yang disoroti wisatawan yang menjadi responden.

Adapun untuk menilai keberhasilan program kegiatan ini adalah :

1. $80 \%$ peserta yang diundang hadir dalam pelatihan.

2. Terlaksananya seluruh kegiatan pelatihan peningkatan pemahaman konsep pariwisata Syariah

3. Terjadinya peningkatan kelulusan dari peserta pelatihan (pre tes dan post tes) sebesar $80 \%$. Pernyataan kepuasan dari peserta pelatihan, dan pemerintah setempat.

\section{Pembahasan}

Sebelum kegiatan dilaksanakan maka dilakukan persiapan-persiapan sebagai berikut:

1. Melakukan studi pustaka tentang konsep wisata Syariah;

2. Melakukan persiapan materi bahan/buku panduan tentang konsep wisata Syariah;

3. Mempersiapakan soal-soal Uji Kompentesi
Awal dan Kompetensi Akhir untuk menguji sejauh mana keberhasilan pelaksanaan kegiatan pengabdian untuk pelaku ekonomi sektor pariwisata di Mesjid Agung Islamic centre kabupaten Rokan Hulu derngan merujuk kepada sumber pedoman penyelenggaraan wisata Syariah (Hery Sucipto \& Fitria Andayani, 2014);

4. Menentukan waktu pelaksanaan dan lamanya kegiatan pengabdian bersama- sama tim pelaksana.

Pelaksanaan kegiatan pengabdian berlangsung 2 hari yaitu dari hari Rabu 6 Desember 2017 dari jam $08.30 \mathrm{~s} / \mathrm{d} 12.00 \mathrm{Wib}$ yang dihadiri sebanyak 10 (sepuluh) orang yang terdiri dari:

a. 2 (dua) orang dari perpustakaan mesjid Agung Islamic Centre

b. 2 (dua) orang dari kantor sekretariat mesjid Agung Islamic Centre

c. 1 (satu) orang dari koperasi Mesjid Agung Islamic Centre

d. 1 (satu) orang dari Mini Market di bisnis centre Mesjid Agung

e. 1 (satu) orang dari kantin di bisnis centre mesjid Agung

f. 1 (satu) orang dari toko pakaian muslim Mesjid Agung

g. 1 (satu) orang dari Studio Photo di bisnis centre Mesjid Agung

h. 1 (satu) orang dari MAIC Fried Chicken di bisnis centre Mesjid Agung

Para pelaku ekonomi sektor pariwisata di Mesjid Agung islamic centre kabupaten Rokan Hulu diberikan penjelasan maksud dari kegiatan pengabdian ini serta memberikan soal Ujian Kompetensi Awal dalam bentuk multiple choice. Selanjutnya diberikan pengarahan tentang Konsep 
Pariwisata Syariah.

Pada hari kedua yaitu kamis 7 Desember 2017 di mulai pada pukul $08.30 \mathrm{~s} / \mathrm{d} 12.00$ Wib yang juga dihadir oleh 10 (sepuluh) orang perserta. Dilakukan pengembalian penilaian terhadap hasil Ujian kompetensi Awal kepada peserta pengabdian disertai koreksi-koreksi dari jawaban yang salah. Dilanjutkan dengan mengulangi penjelasan materi/bahan tentang konsep wisata syariah. Pada akhir dari penjelasan dilakukan lagi pemberian soal Ujian Kompetensi Akhir untuk menilai seberapa besar terjadinya peningkatan pemahaman tentang konsep wisata syariah.

\section{KESIMPULAN DAN SARAN}

\section{Kesimpulan}

Dari kegiatan pengabdian pada masyarakat ini dapat disimpulkan bahwa Pengetahuan dan pemahaman pelaku ekonomi sektor pariwisata di Mesjid Agung Islamic centre kabupaten Rokan Hulu tentang konsep wisata syariah menjadi meningkat.

\section{Saran}

Mengingat besarnya manfaat kegiatan pengabdian pada masyarakat ini, maka selanjutnya perlu:

1. Mengadakan pelatihan serupa pada setiap pelaku ekonomi sektor pariwisata syariah yang ada di kabupaten Rokan Hulu selain di Mesjid Agung islamic centre.

2. Adanya kesinambungan dan monitoring program pasca kegiatan pengabdian ini sehingga pelaku ekonomi sektor pariwisata syariah yang ada di kabupaten Rokan Hulu benar- benar dapat menerapkan pemahaman mereka tentang konsep wisata syariah.

\section{DAFTAR PUSTAKA}

\section{A.T. Sulistiyani. (2004). Kemitraan dan Model Model Pemberdayaan. Yogyakarta: Gaya Media.}

Bambang Udoyono. (2008). Sukses Menjadi Pemandu Wisata Profesional, Kesaint Blanc: Jakarta

Chookaew, S., Chanin, O., Charatarawat, J., Sriprasert, P., \& Nimpaya, S. Increasing Halal Tourism Potential at Andaman Gulf in.Journal of Economics, Business and Management, III (7), 277-279.201.

Gabri, Dastio. Wisata Religi Masjid Agung Madani Rokan Hulu. Retrieved from www.sengpaku.blogspot.co.id/2017/01/wisatareligi-masjid-agung-madani-rokan-hulu.html

Hery Sucipto dan Fitria Andayani (2014). Wisata Syariah: Karakter, Potensi, Prospek dan Tantangannya. Jakarta: Grafindo Books Media dan Wisata Syariah Consuting.

HR. Bukhari, no. 6018. Muslim, no. 47, dari Abi Hurairah.

MasterCard, \& Crescenrating. (2015). Global Muslim Tourism Index 2015.,http:// www.crescenrating.com/mastercardcrescenrating-globalmulsim-travel-index.html 
Maulana M. Hamzah \& Yudi Yudiana. (2015). Analisis Komparatif Potensi Industri Halal dalam Wisata Syariah dengan Konvensional. Dipetik Agustus 4, 2015, dari http:// catatanek 18.blogspot.co.id/2015/02/analisis -komparatif potensiindustri .html

Moira, P., Mylonopoulos, D., \& Kontoudaki, A.The Management of Tourist's Alimentary Needs by the Tourism Industry.International Journal of Culture and Tourism Research, 5 (1), 129-140.2012.

Murphy, Peter E. (1987), Tourism A Community Approach, Methuen, New York.

Reuters, T., \& DinarStandard. (2014). State of the Global Islamic Economy 2014-2015 Report. Dubai: Dubai the Capital of Islamic Economy RPJMN 2015-2019 (BAPPENAS)

Sapudin,, F. Adi, \& Sutomo. Analisis Perbandingan Hotel dan Pariwisata Syariah dengan Konvensional.Bogor: Magister Manajemen Syariah IPB 2014.

Sahida, W., Rahman, S. A., Awang, K., \& Man, Y. C (2011).The Implementation of Shariah Compliance Concept Hotel: De Palma. 2nd International Conference on $\mathrm{Hu}-$ manities, Historical and Social Sciences.17, pp. 138-142. Singapore: IACSIT Press.

Sofyan Riyanto (2012). Prospek Bisnis Pariwisata Syariah. Jakarta: Buku Republika.
State of The Global Islamic Economy 2013 Report

Suheri Tanjung (2015), Analisis Kualitas Pelayanan Pramuwisata Di Istana Asserayah Hasyimiah Rokan Hulu Sri Indrapura, Tourism Department Faculty of Social and Political Science Riau University JOM FISIP Vol.7Oktober

Undang-Undang Republik Indonesia Nomor 10 Tahun 2009 tentang Kepariwisataan

www.parekraf.go.id, 2014

www.riau.go.id/home/content /2016/10/21/6034potensi-wisata -kebudayaan-riau-harus-terusberkembang

www.riau.go.id/home/content/24/kab-Rokan Hulu www.travel.okezone.com, 2014. 